\title{
PERAN PPAT DALAM PENYERAHAN FASILITAS UMUM DAN FASILITAS SOSIAL OLEH PENGEMBANG PERUMAHAN KEPADA PEMERINTAH KOTA SEMARANG
}

\author{
Yunianto Wahyu Sadewa*' Jawade Hafidz ${ }^{* *}$ \\ * Mahasiswa Program Magister (S2) Kenotariatan Fakultas Hukum UNISSULA, email : yuniantowahyu@gmail.com \\ ** Dosen Fakultas Hukum UNISSULA, email: jawade@unissula.ac.id
}

\section{ABSTRACT}

Submission of location permit is required in the provision of social facilities and public facilities. Licensing is a unified process in the housing that is from the beginning to the management stage. The research that the author did in the city of Semarang, Central Java province. The research method applied in this research is the sociological juridical approach.

The results of this study are: The role of PPAT has not been directly due to the formation of regulations from the central government and in the city of Semarang has not involved PPAT in the formation of Regional Regulations Semarang City. Factors affecting PPAT in the delivery of public facilities (fasum) and social facilities (fasos) to the Government of Semarang City, the pre-transaction stage where the developer must already have all the relevant licensing in the pre-transaction process until after / after the transaction developer must providing all social facilities and social facilities as promised during the first bidding process. Legal consequences with future PPAT role is expected to provide infrastructure and facilities from initial procurement to delivery based on the principles of openness, accountability, legal certainty, written warning. Suggestion from this research is for PPAT should the process of procurement and management of public facility (fasum) and social facility (fasos) is arranged pursuant to agreement of sale and purchase agreement (PPJB), for Government of Fasum and Fasos which have finished development process should be submitted from the developer to Government so that the responsibility for the management of public facilities and fasos is in the government, and for the National Land Agency (BPN), there must be a harmonious relationship between PPAT and the Land Office as an equal partner.

Keywords: Role of PPAT, Submission of Social Facility, Semarang City Government

\section{PENDAHULUAN}

Dasar diberlakukannya Undang-Undang Pokok Agraria, Undang-Undang Nomor 5 Tahun 1960 adalah Pasal 33 ayat (3) Undang-Undang Dasar Tahun 1945. Diantara tujuan pokok dibentuknya Undang-Undang Pokok Agraria (UUPA) yaitu meletakkan dasar-dasar untuk memberikan kepastian hukum mengenai hak atas tanah. Kepastian hukum yang dimaksudkan mencakup: kepastian mengenai subyek hukum atas tanah (orang atau badan hukum); kepastian mengenai letak, batas, ukuran / luas tanah atau kepastian mengenai obyek hak; dan kepastian mengenai status hak atas tanah yang menjadi landasan hubungan-hubungan antar tanah dengan orang/ badan hukum. ${ }^{1}$

\footnotetext{
${ }^{1}$ Harsono Boedi, Hukum Agraria Indonesia, Sejarah Pembentukan Undang-Undang Pokok
}

Pengajuan izin lokasi merupakan hal yang disyaratkan dalam pengadaan fasilitas sosial dan fasilitas umum. Perizinan tersebut adalah proses yang menyatu dalam pembagnunan perumahan yaitu dari tahap awal hingga pengelolaan.

Kewenangan PPAT yaitu membuat alat bukti terkait perbuatan hukum yang bersangkutan mengenai hak atas tanah, dan hak milik atas satuan rumah susun sebagai dasar pendaftaran atau pemisahan, sehingga Kantor Peratanahan hanya memerlukan data yang tersaji dalam bentuk akta yang dibuat oleh PPAT dalam kegiatan pendaftaran tanah.

PPAT merupakan suatu profesi yang membutuhkan peraturan yang tegas dan jelas dalam pelaksanaan tugasnya. Peraturan tersebut adalah sebagaimana yang tertuang dalam Peraturan

Agraria, Isi, dan Pelaksanaannya, Cet. Kedua, (Djambatan:Jakarta, 1997),hlm. 48. 
Pemerintah (PP) No. 37 Tahun 1998 tentang Peraturan Jabatan Pejabat Pembuatan Akta Tanah, dimana dalam peraturan tersebut termuat kode etik dan aturan bagi PPAT dalam melaksanakan tugasnya.

\section{Rumusan Masalah}

1. Bagaimana Peran PPAT terkait penyerahan Fasilitas Sosial (fasos) dan Fasilitas Umum (fasum) dari pihak Pengembang ke Pihak Pemerintah Kota Semarang berdasarkan Peraturan Daerah (Perda) No. 6 Tahun 2015 tentang Penyediaan dan Penyerahan Prasarana, Sarana dan Utilitas pada Kawasan Industri, Perdagangan, Perumahan dan Permikiman?

2. Faktor-faktor apa yang mempengaruhi PPAT dalam Penyerahan Fasilitas Sosial dan Fasilitas Umum kepada pihak Pemerintah Kota Semarang?

3. Bagaimana akibat hukum peran PPAT dalam proses Penyerahan Fasilitas Sosial dan Fasilitas Umum dari pihak pengembang kepada pihak pemerintah Kota semarang berdasarkan Peraturan Daerah (Perda) No. 6 Tahun 2015 tentang Penyediaan dan Penyerahan Prasarana, Sarana dan Utilitas pada Kawasan Industri, Perdagangan, Perumahan dan Permukiman?

\section{Metode Penelitian}

Penelitian yang penulis lakukan yakni di Kota Semarang, propinsi Jawa Tengah. Adapun metode penelitian yang diterapkan dalam penelitian ini adalah pendekatan yuridis sosiologis.

\section{PEMBAHASAN}

\section{Peran PPAT dalam Penyerahan Fasilitas Sosial (fasos) dan Fasilitas Umum (fasum)}

Akta PPAT merupakan bukti perbuatan hukum telah dilakukan oleh para pihak. Bukti ini menjadi dasar bagi pemegang hak terakhir untuk mendafatarkan aktanya ke Kantor Pertanahan. Peralihan hak didasarkan pada Akta PPAT sehingga meskipun telah terbit sertipikat, Akta PPAT tidak serta merta tidak berlaku. Akta PPAT seharusnya tetap disimpan jika suatu saat ada gugatan pihak yang berkeberatan.

Menurut PP No. 37/1998 tentang Peraturan Jabatan PPAT, kegiatan PPAT membantu Kepala Kantor Pertanahan dan Pemerintah Daerah, dalam hal ini Kota Semarang dalam proses penyerahan fasilitas sosial dan fasilitas umum dari pihak pengembang ke pihak pemerintah kota (Pemkot) Semarang untuk kepentingan fasilitas sosial dan umum.
PPAT memiliki peran memberikan kepastian hukum bagi masyarakat manakala ia dapat menjamin akurasi dari data yang dituangkannya ke dalam Akta. Fungsi hukum untuk keadilan terpenuhi ketika keadilan tercapai dalam arti bahwa hak pembeli dan penjual tidak terzolimi satu sama lain. Pengembang mendapatkan haknya dan fasos fasum harus diberikan ke Pemerintah Kota Semarang tidak diganggu haknya sebagai pemilik yang baru atas HAT tersebut.

Pentingnya PPAT dalam menerapkan asas kepastian hukum adalah karena PPAT merupakan Pejabat Umum yang membantu Kepala Kantor Pertanahan dalam proses pensertipikatan dalam hal terjadi pemisahan HAT. Akta PPAT menjadi dasar pembuatan sertipikat oleh Kantor Pertanahan, jika aktanya tidak terjamin keakuratannya maka akan berakibat terjadi kesalahan pada sertipikat. Kesalahan pada sertipikat akan menghilangkan fungsi sertifikat sebagai bukti kepemilikan yang memiliki kepastian hukum.

Faktor-Faktor yang mempengaruhi PPAT dalam proses penyerahan Fasilitas Sosial dan Fasilitas Umum kepada Pemerintah Kota Semarang

\section{Tahap Pra Transaksi}

Tahap pra Transaksi merupakan tahap dimana pihak konsumen berada dalam proses pencarian informasi terkait harga dan syarat-syarat yang harus dipenuhi, serta mempertimbangkan fasilitas yang diinginkan dan kondisinya. Tahap ini menuntut developer untuk memiliki segala macam perizinan mulai dari izin prinsip, izin lokasi, sertifikat bukti pemilikan hak, surat pemberitahuan pajak tahunan, dan izin mendirikan bangunan.

\section{Tahap Transaksi}

Tahap transaksi merupakan tahap dimana konsumen dan developer melakukan kesepakatan. Transaksi ini tertuang dalam perjanjian pengikatan jual beli fasilitas sosial (perumahan) dan ditandatangani. Penandatanganan ini merupakan suatu perbuatan hukum dari kedua belah pihak yang mempunyai akibat hukum yaitu terwujudnya hak dan kewajiban bagi kedua belah pihak.Tahap ini, konsumen membayar harga yang disepakati dalam perjanjian pengikatan jual beli (PPJB) tersebut, sedangkan pihak developer akan membangun rumah yang konsep dan waktu pembangunannya sesuai dengan ketentuan yang termuat dalam PPJB.

\section{Tahap Purna/Pasca Transaksi}


Tahap ini merupakan tahap dimana pihak konsumen telah membayar harga sesuai dengan ketentuan PPJB, dan pihak developer telah menyerahkan rumah beserta fasilitasnya dan dokumen penting berupa sertifikat bukti hak milik yang telah diatasnamakan konsumen.Penyerahan fasilitas sosial dan fasilitas umum dari pihak developer terjadi pada tahap ini. Fasilitas sosial dalam hal ini adalah fasilitas yang memberikan pelayanan kepada konsumen yang meliputi fasilitas pendidikan, peribadatan, kesehatan, pelayanan umum dan Pemerintahan. ${ }^{2}$

Pengawasan yang kurang dari pihak Pemerintah Kota terhadap Pengadaan dan Pengelolaan Fasilitas sosial dan Fasilitas Umum oleh pihak Pengembang di Kota Semarang. Penyerahan fasilitas umum dan fasilitas sosial di Kota Semarang dapat dirinci sebagai berikut: $40 \%$ Fasum dan prasarana yang telah dibangun telah diserahkan dan 50\% dari Fasum tersebut telah terjual; 100\% Fasum dan prasarana yang telah dibangun telah diserahkan dan $90 \%$ dari Fasum tersebut telah terjual. Pemeliharaan Fasum, Fasos dan Prasarana Lingkungan yang telah diserahkan merupakan kewajiban dari pihak pengembang (developer) sampai semua kavling telah dibangun dan terjual.

\section{Akibat Hukum Peran PPAT dalam proses penyerahan fasilitas sosial dan fasilitas umum dari pihak pengembang kepada pihak pemerintah kota semarang berdasarkan peraturan daerah (perda) no. 6 tahun 2015 tentang penyediaan dan penyerahan prasarana, sarana dan utilitas pada kawasan industri, perdagangan, perumahan dan permikiman.}

Pemerintah Kota Semarang mempunyai kewenangan yang meliputi pencatatan prasarana sarana utilitas, pemeliharaan dan pengembangan, penggunaan dan/atau pemanfaatan serta merubah prasarana sarana utilitas suatu kawasan yang berada di daerah kota Semarang. Pelaksanaan kewenangan tersebut, Pemerintah Kota Semarang dapat dilimpahkan kepada dinas terkait yaitu dinas yang sesuai dengan tugas, pokok dan fungsinya. Pemerintah Kota Semarang juga dapat bekerjasama

\footnotetext{
${ }^{2}$ Wawancara dengan Pratita Arima Putri Marketing PT. SHOUL BAFAZA Barkah (Pengembang Perumahan Griya Buana Bangetayu) pada tanggal 19 Mei 2017, Pukul 11.15 WIB.
}

dengan pengembang dalam pengadaan prasarana sarana. $^{3}$

Peringatan tertulis dimaksudkan untuk mengingatkan pengembang untuk menjalankan kewajibannya yang lalai dilakukan atau sengaja tidak dilakukan. Sikap tidak menghiraukan adanya surat peringatan dari pihak Pemerintah mengakibatkan pengembang terkait dapat dicabut surat izin usahanya dalam mengembangkan/ mengadakan prasaran sarana di kota Semarang. Pemberitahuan itu dilakukan secara publik oleh pihak Pemerintah melalui media massa baik cetak maupun on-line. Ketentuan ini diatur dalam Pasal 29 Perda ini tentang sanksi administrasi. ${ }^{4}$

\section{PENUTUP}

\section{Kesimpulan}

a. Peran PPAT belum secara langsung karena keharusan menyerahkan Fasilitas Sosial (Fasos) dan Fasilitas Umum (Fasum) oleh Pengembang kepada pihak Pemerintah Kota telah diatur melalui peraturan dari pemerintah pusat dan di kota Semarang belum melibatkan PPAT dalampembentukan Peraturan Daerah Kota Semarang, sehingga di kota Semarang Perda tersebut seperti tidak terlaksana, terbukti dengan banyaknya pengembang yang belum menyerahkan fasos dan fasumnya, sehingga menimbulkan permasalahan baru.

b. Faktor-faktor yang mempengaruhi PPAT dalam penyerahan Fasilitas Sosial dan Fasilitas Umum kepada Pemerintah Kota Semarang.

1) tahap pra transaksi dimana developer harus sudah mempunyai segala macam perizinan yang terkait dalam proses pra transaksi. 2) tahap transaksi, developer harus menjalankan kesepakatan Perjanjian Pengikatan Jual Beli (PPJB) perumahan. 3) Tahap purna/pasca transaksi developer menyerahkan fasilitas sosial dan fasilitas umum sebagaimana yang telah diperjanjikan pada tahap pertama dan jaminan pemeliharaan dan pengelolaan lingkungan perumahan.

\footnotetext{
${ }^{3}$ Wawancara dengan Ibu Aning Siti Soelastri, SE., MM. (Kasubag Umum dan Kepegawaian BAPPEDA Kota Semarang) pada tanggal 22 Mei 2017, pukul 12.30 WIB.

${ }^{4}$ Wawancara dengan Ibu. Aning Siti Soelastri, $\mathrm{SE}$, MM, (Kasubag Umum dan Kepegawaian BAPPEDA Kota Semarang) pada tanggal $22 \mathrm{Mei}$ 2017, pukul 12.30 WIB
} 
c. Akibat hukum peran PPAT dalam proses Penyerahan Fasilitas Sosial dan Fasilitas Umum dari pihak Pengembang ke Pemerintah Kota Semarang berdasarkan Perda No. 6 Tahun 2015 tentang Penyediaan dan Penyerahan Prasarana, Sarana dan Utilitas pada Kawasan Industri, Perdagangan, Perumahan dan Permukiman. Dengan peran PPAT kedepan diharapkan penyediaan prasarana dan sarana dari pengadaan awal sampai penyerahan mengacu pada prinsip keterbukaan, akuntabilitas, kepastian hukum, peringatan tertulis dimaksudkan untuk mengingatkan pengembang untuk menjalankan kewajibannya yang lalai dilakukan atau sengaja tidak dilakukan.

\section{Saran}

a. Untuk PPAT: pentingnya pengadaan Perjanjian Perikatan Jual Beli (PPJB) dalam Pengadaan dan pengelolaan fasilitas sosial dan fasilitas umum.

b. Untuk Pemerintah: pemerintahlah yang bertanggung jawab penuh dalam pengelolaan fasilitasfasilitas tersebut.

c. Untuk Masyarakat/BPN: Harus terjalin hubungan yang harmonis antara PPAT dan Kantor
Pertanahan sebagai mitra sejajar yang saling mendukung dalam tugas pertanahan.

\section{DAFTAR PUSTAKA}

Boedi, Harsono.1997. Hukum Agraria Indonesia, Sejarah Pembentukan Undang-Undang Pokok Agraria, Isi dan Pelaksanaannya. Djambatan. Jakarta.

Hasil Wawancara dengan Pratita Arima Putri Marketing PT. SHOUL BAFAZA BARKAH (Pengembang Perumahan Griya Buana Bangetayu) pada tanggal 19 Mei 2017, pukul 11.15 WIB

Hasil Wawancara dengan Ibu. Aning Siti Soelastri, SE, MM, (Kasubag Umum dan Kepegawaian BAPPEDA Kota Semarang) pada tanggal 22 Mei 2017, pukul 12.30 WIB 